\title{
Overview of Iraqi experience in management of acute promyelocytic leukemia
}

\author{
Waseem F Al-Tameemi' ${ }^{1}$ Zahra'a S. Shakir $^{2}$ \\ ${ }^{1}$ Professor, Dept. of Medicine (Hematology), College of Medicine, Al-Nahrain University \\ ${ }^{2}$ Specialist Hematologist, Baghdad Teaching Hospital, Medical City complex Hospital
}

Received: 30.3 .2021

Accepted: 25.4 .2021

\begin{abstract}
Objectives: In Iraq, leukemia is the $4^{\text {th }}$ most common cancer, and acute promyelocytic leukemia contributes to $2.83 \%$ and $3.18 \%$ of leukemia in Iraqi males and females respectively. The aim of this study is to review the presentation and management outcome of patients with acute promyelocytic leukemia in Iraq.

Methods: A hospital-based cross-sectional study was conducted over the period of 15 months in different hematology centers. A total of 58 patients with acute promyelocytic leukemia were enrolled in this study (53 newly diagnosed and 5 relapsed cases). Diagnosis was based on morphology with or without cytogenetic study.

Results: The mean age was 33.1 \pm 13.8 years, with slight female predominance. Most cases presented at winter season ( $39.7 \%)$. Sanz severity scoring classification of patients as $(25.9 \%)$ with low risk, $(53.4 \%)$ intermediate risk, and (20.6\%) high risk disease. Induction protocol consist of chemotherapy plus ATRA in (58\%), while (36.2\%) received only ATRA plus ATO. At the end of induction, (86.2\%) of patients had complete remission, while only $13.8 \%$ had failure of induction and death. Induction mortality was higher in those who had received chemotherapy-based regimens. At relapse, a second complete remission had been achieved in 4 out of 5 cases (80\%).

Conclusion: There is a predilection of acute promyelocytic leukemia to young age group and winter season presentation. The choice of non-chemotherapy regimens, especially for the low and intermediate risk group, showed no drawback in complete remission rate. Disease outcome in Iraq has improved over several years due to increasing experience with using different regimen.
\end{abstract}

Keywords: Acute promyelocytic leukemia, ATRA, Arsenic Trioxide, Chemotherapy, Iraq

Corresponding to:

Waseem F Al-Tameemi, Professor, Dept. of Medicine

(Hematology), College of Medicine, Al-Nahrain University

$\bowtie$ drwaseem72@gmail.com

Phone No.: + 9647901555115

\section{Introduction}

Acute promyelocytic leukemia (APL) is a rare disease, comprising around 5-10\% of AMLs of the adult, with an estimated incidence of $0.1 / 100000$ in Western countries ${ }^{1}$.

In Iraq, APL contributes to $0.84 \%$ of all leukemia cases. It constitutes $2.83 \%$, and $3.18 \%$ of leukemias in Iraqi males and females respectively, according to the annual report of Iraqi cancer registry 2018.

The characteristic cytogenetics translocation $t(15 ; 17)$ was found in most of the cases with the resultant abnormal fusion between promyelocytic leukemia gene and retinoic acid receptor (PML/RARA) ${ }^{1}$ that results in a malignant cell ${ }^{2}$. Classical cases show strong positivity for CD33, expression of $\mathrm{CD} 13$ and $\mathrm{CD} 117$, infrequent expression of HLA-DR and CD34, and lack of CD11a, CD11b and CD14 ${ }^{1}$. 
In 1985, all-trans retinoic acid (ATRA) had made a big change in managing APL. Adding ATRA to chemotherapy, up to $90-95 \%$ were able to achieve complete remission (CR). ${ }^{3}$

Since1990s, the use of arsenic trioxide (ATO) had added more to the outcome of newly diagnosed as well as relapsed refractory APL. ${ }^{3}$ It is worthy to say that as a result of 40 years of clinical trials, the most fatal subtype of AML, the APL, is being considered now as the most curable. $^{4}$

The stratification of APL risk according to Sanz stratification based on WBC and platelet counts remains the most reliable and validated way to rapidly identify high-risk APL patients. ${ }^{5}$

Sanz et al defined patients with $\mathrm{WBC} \leq 10000 / \mu \mathrm{l}$ and platelet count $>40000 / \mu \mathrm{l}$ as low risk, WBC $\leq 10 \quad 000 / \mu \mathrm{l}$ and platelet count $\leq 40000 / \mu \mathrm{l}$ as intermediate risk and $\mathrm{WBC}>10000 / \mu \mathrm{l}$ as high risk. ${ }^{6}$

Low-risk disease is better treated with less intensive regimens than those patients presenting with high-risk disease. ${ }^{7}$

The combination of ATO plus ATRA was used as first line management at least in the low/intermediate risk group ${ }^{8,9}$ as compared with ATRA plus chemotherapy, this regimen is equally effective if not better, and it carries more treatable side effects. ${ }^{10}$

For high risk patients, it is recommended to use ATRA plus anthracycline-based chemotherapy ${ }^{11}$ with a CR of more than $90 \%$. The early death of APL is the main cause of treatment failure, caused mostly by CNS bleeding. ${ }^{12}$

Those patients who receive induction by chemotherapy free approaches, the recommended consolidation is by 4 courses of ATO and 7 courses of ATRA. While patients who received induction by conventional ATRA/ chemotherapy approach, consolidation will be a
2-3 courses of anthracycline based chemotherapy. ${ }^{11}$

Till now, cytarabine in consolidation, at a high or intermediate dose, given in at least one cycle, for high-risk patient $<60$ years, will decrease the risk of relapse, but no change in overall survival (OS) 11

A maintenance regimen of ATRA, 6mercaptopurine (6-MP) and methotrexate (MTX) for 2 years had adopted for all patient according to routine guidelines to get less relapse rate on high-risk patient (APL 2000 and APL 93). ${ }^{13}$

The new recommendation for patients treated with chemotherapy-free approaches is not to use maintenance ${ }^{11 .}$

This study aims to review of APL course in terms of patient characters, presentation, risk stratification, and different management approaches, as well as the treatment related complications and outcomes in Iraq.

\section{Methods}

\section{Study settings and design}

A hospital-based case series study was conducted in different hematology centers in Baghdad, including Baghdad Teaching Hospital hematology center and the private nursing hospital in the Medical City Complex, hematology department in Al-Imamian AlKadhimain medical city, and the National Center of Hematology/ Al-Mustansiriya University throughout the period from July 2018 till September 2019, i.e., 15 months duration.

All patients were informed about the research, their consent were taken for participation.

\section{Selection of study subjects}

It includes all patients (15 years or more) who were diagnosed with APL based on morphology 
The Medical Journal of Basrah University

(2021); 39(1): 21-30

(by complete blood count (CBC), blood film, bone marrow aspirate and biopsy), with or without suggestive Flow cytometry and, whenever possible, with genetic confirmation by presence of $\mathrm{t}(15,17)$ or PML/RARA by RT-PCR.

\section{Data collection}

Through direct interviewing of patients and reviewing their file registry, the demographic data of APL Iraqi patients were collected. All cases were confirmed by reviewing the laboratory investigations: $\mathrm{CBC}$, blood film, bone marrow aspirate and biopsy, flow cytometry, and cytogenetics.

Patients were followed throughout the study period in order to assess the outcome by phone contact using social media technology.

\section{Definitions of outcome}

Complete remission (CR): The disappearance of all disease features in response to treatment. It is based on the following criteria: the disappearance of abnormal promyelocytes on bone marrow aspirate, normalization of coagulation and fibrinolysis parameters, a neutrophil count of greater than $1,500 / \mu \mathrm{L}$, a platelet count greater than $100,000 / \mu \mathrm{L}$, and no transfusion requirement.

Overall survival (OS): The length of time from either the date of diagnosis or the start of treatment for a disease, till death in weeks

Treatment failure: Resistant to treatment or death from any cause.

\section{Statistical Analysis}

Data were analyzed using statistical package for the social sciences (SPSS version 23) computer software program. Analytic statistics as Student $\mathrm{t}$ test used to find association between categorical variables and continuous variables, and fisher exact test to find association between
Overview of Iraqi experience in management of acute promyelocytic leukemia

two categorical variables. Survival analysis was done by log rank and overall survival by KaplanMeier test for one year duration. The p-value less than or equal to 0.05 was considered to be statistically significant.

\section{Results}

\section{Demographic data}

A total of 58 APL patients were enrolled in this study. The mean age was $33.1 \pm 13.8$ years. The disease was more predominant in females, with a male to female ratio of 1:1.4. Most of the patients, $23(39.7 \%)$, were first presented at winter. (Table 1)

\begin{tabular}{|c|c|c|c|}
\hline Variables & Description & No. & $\%$ \\
\hline \multirow{6}{*}{$\begin{array}{l}\text { Age at diagnosis } \\
\text { (years) }\end{array}$} & $<20$ years & 13 & 22.4 \\
\hline & 20-29 years & 14 & 24.1 \\
\hline & $30-39$ years & 11 & 19 \\
\hline & $40-49$ years & 11 & 19 \\
\hline & $\geq 50$ years & 9 & 15.5 \\
\hline & Mean \pm SD (Range) & \multicolumn{2}{|c|}{$33.1 \pm 13.8(5-62)$} \\
\hline \multirow[b]{2}{*}{ Gender } & Male & 28 & 48.3 \\
\hline & Female & 30 & 51.7 \\
\hline \multirow[b]{2}{*}{ Residence } & Baghdad & 38 & 65.5 \\
\hline & Other & 20 & 34.5 \\
\hline \multirow{4}{*}{$\begin{array}{l}\text { Seasonal of } \\
\text { presentation }\end{array}$} & $\begin{array}{c}\text { Winter (December- } \\
\text { February) }\end{array}$ & 23 & 39.7 \\
\hline & Spring (March-May) & 15 & 25.9 \\
\hline & Summer (June-August) & 10 & 17.2 \\
\hline & $\begin{array}{l}\text { Autumn (September- } \\
\text { November) }\end{array}$ & 10 & 17.2 \\
\hline
\end{tabular}

\section{Clinical presentations:}


The Medical Journal of Basrah University

(2021); 39(1): 21-30

Majority of the patients (79\%) were suffering from coagulopathy at time of presentations in form of bleeding, apart from 3 patients who suffered from thrombosis. Organomegally, including gum hypertrophy, was seen in only $(5.2 \%)$ of patients. (Figure 1).

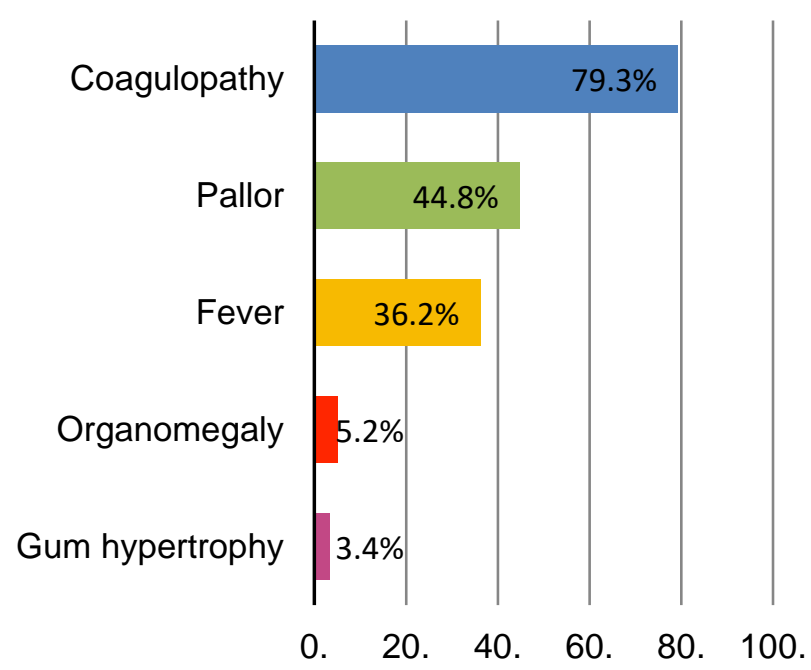

Figure 1: Distribution of Clinical Presentations

\section{Hematological parameters:}

Pancytopenia was the presenting manifestation in $41 \%$ of patients. All patients had been diagnosed on morphological basis by having malignant promyelocytes in peripheral blood and/or bone marrow, while only (25.9\%) of patients had flow cytometry for diagnosis, and (37.9\%) had cytogenetically proved disease. (Table 2)

\section{Risk stratification}

Based on Sanz score categories, 20.6\% were labeled as high risk, unlike intermediate and low risk groups that constituted (53.4\%), (25.9\%) respectively. A classical APL morphology was described in $(82 \%)$.

\section{Treatment strategy: Induction protocols}

http://dx.doi.org/10.33762/mjbu.2021.129847.1068
Overview of Iraqi experience in management of acute promyelocytic leukemia

Unfortunately, two patients had passed shortly after receiving ATRA alone. One more patient had received ATRA alone and refused neither taking chemotherapy nor ATO. In the remaining 55 patients, ATRA (in a dose of $45 \mathrm{mg} / \mathrm{m}^{2}$ ) was either combined with ATO (36.2\%) in a dose of $0.15 \mathrm{mg} / \mathrm{kg}$, or more commonly combined with chemotherapy $(58.6 \%)$ like doxorubicin in a dose of $30 \mathrm{mg} / \mathrm{m}^{2}$, given in 4 doses at days 2, 4, 6 and 8 from starting ATRA. Induction duration ranges between 30-39 days in (32.6\%), between 40-49 days in $10.3 \%$ of cases, between 50-59 days in $22.4 \%$, and $\geq 60$ days duration in only $5.2 \%$.

\begin{tabular}{|c|c|c|c|}
\hline Test & Parameters & Mean \pm SD & Range \\
\hline \multirow[t]{3}{*}{ CBC } & 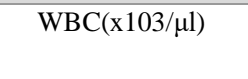 & $\begin{array}{c}10.95 \pm 19.8 \\
1\end{array}$ & $\begin{array}{c}(0.30- \\
124)\end{array}$ \\
\hline & Haemoglobin (g/dl) & $8.34 \pm 1.96$ & $\begin{array}{l}(4.6- \\
13.5)\end{array}$ \\
\hline & Platelets $(x 103 / \mu 1)$ & $\begin{array}{c}36.97 \pm 31.5 \\
5\end{array}$ & $\begin{array}{l}(7.1- \\
205)\end{array}$ \\
\hline Blood film & $\begin{array}{c}\text { Malignant } \\
\text { Promyelocytes \% }\end{array}$ & $\begin{array}{c}33.76 \pm 34.9 \\
5\end{array}$ & $(0-96)$ \\
\hline BM study & $\begin{array}{c}\text { Malignant } \\
\text { Promyeloctes } \%\end{array}$ & $\begin{array}{c}62.95 \pm 30.0 \\
5\end{array}$ & $(5-95)$ \\
\hline \multirow[t]{2}{*}{$\begin{array}{l}\text { Coagulation } \\
\text { study }\end{array}$} & PT (sec) & $16.33 \pm 5.62$ & $\begin{array}{c}(11.2- \\
39)\end{array}$ \\
\hline & PTT (sec) & $32.13 \pm 6.54$ & $\begin{array}{c}(20- \\
59.6)\end{array}$ \\
\hline \multicolumn{2}{|c|}{ Methods used for diagnosis } & No. & $\%$ \\
\hline Morphology & $\begin{array}{c}\text { Blood film and/ or } \\
\text { BM study }\end{array}$ & 58 & 100 \\
\hline $\begin{array}{c}\text { Immune } \\
\text { phenotyping }\end{array}$ & Flowcytometry & 15 & 25.9 \\
\hline Genetic & $\begin{array}{l}\text { Cytogenetic or } \\
\text { molecular }\end{array}$ & 22 & 37.9 \\
\hline \multicolumn{4}{|c|}{$\begin{array}{l}\text { SD, standard deviation; CBC, complete blood count; WBC, white } \\
\text { blood cell count; PT, prothrombin time; aPTT, activated partial } \\
\text { thromboplastin time; BM, bone marrow }\end{array}$} \\
\hline
\end{tabular}

\section{Induction outcome}

CR was achieved in $86.2 \%$ (50) of patients; while the rest, $13.8 \%$ (8), had died due to bleeding, Page 24 
The Medical Journal of Basrah University

(2021); 39(1): 21-30

infection, or differentiation syndrome. The most frequent complications of induction were neutropenic fever and differentiation syndrome (Figure 2)

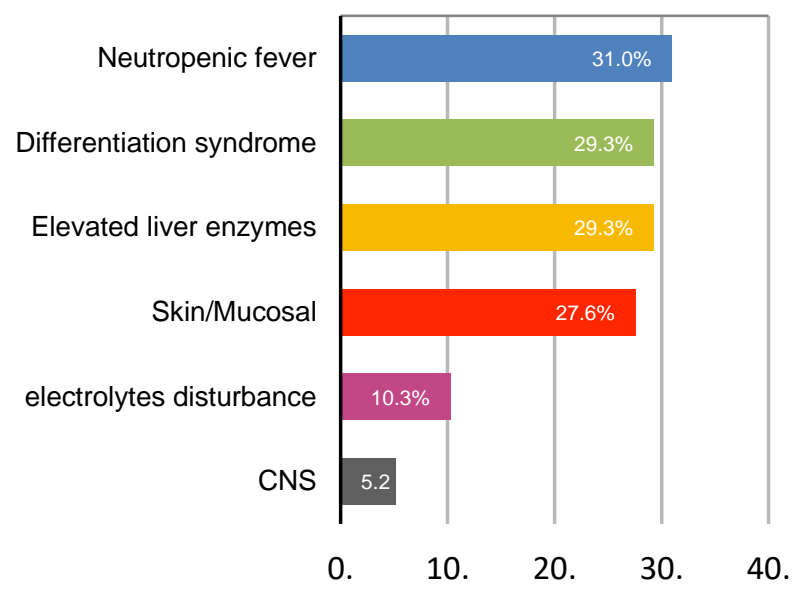

Figure 2 : Complications during induction

\section{Consolidation protocols}

Only 44 patients with $\mathrm{CR}$ had received consolidation courses, as 6 patients had not received consolidation for different reasons (lost to follow up, referral, refusal of treatment).

They were either combinations of ATRA + ATO $(61.3 \%)$, or ATRA plus chemotherapy in (38.7\%). During consolidation, one patient had died because of sepsis.

\section{Maintenance course:}

Only (34) patients had finished consolidation courses whereas $53 \%$ (18) had kept on maintenance but the other $47 \%$ (16) had stopped treatment with no maintenance.

\section{Outcome interpretation}

Overview of Iraqi experience in management of acute promyelocytic leukemia

The mean age in patients who had failure of induction therapy due to death was 37.8 years while the mean age in patients who had complete remission (CR) was 32.3 years with no significant difference between age of patients and induction outcome $(p=0.29)$.

There was no significant association between gender, and the induction outcome $(\mathrm{p}=0.25,0)$. (Table 3)

\begin{tabular}{|c|c|c|c|c|}
\hline \multirow{2}{*}{ Variables } & \multirow{2}{*}{ Description } & \multicolumn{2}{|c|}{ Induction outcome } & \multirow{2}{*}{$\mathrm{P}$ value } \\
\hline & & Death & CR & \\
\hline $\begin{array}{c}\text { Age at } \\
\text { diagnosis } \\
\text { (years) }\end{array}$ & Mean age & 37.8 & 32.3 & $0.29 *$ \\
\hline \multirow[t]{2}{*}{ Gender } & Male & $2(7.1 \%)$ & $\begin{array}{c}26(92.9 \% \\
)\end{array}$ & \multirow[t]{2}{*}{$0.25^{* *}$} \\
\hline & Female & $6(20 \%)$ & $24(80 \%)$ & \\
\hline \multirow[t]{2}{*}{ Residence } & Baghdad & $5(13.2)$ & $\begin{array}{c}33(86.8 \% \\
)\end{array}$ & \multirow[t]{2}{*}{$0.56^{* * *}$} \\
\hline & Other & $3(15 \%)$ & $17(85 \%)$ & \\
\hline CR, com & te remissio & $\begin{array}{l}\text { tudent } T \\
\text { cant } \leq 0 \text {. }\end{array}$ & * fisher $\mathrm{e}$ & test, \\
\hline
\end{tabular}

The mean WBC count was higher in those with failure of induction therapy due to death (24.1 $\mathrm{x} 10^{3} / \mathrm{ml}$ ) compared with achievement CR outcome $\left(8.4 \times 10^{3} / \mathrm{ml}\right)$ which is of statistical significance $(\mathrm{p}=0.038)$.

The mean hemoglobin level was lower in case of induction failure $(6.5 \mathrm{~g} / \mathrm{dl})$ than that for $\mathrm{CR}$ group $(8.5 \mathrm{~g} / \mathrm{dl})$ which is also significant $(\mathrm{p}=$ 0.006).

There was no significant difference in relation to platelets count with induction outcome $(p=0.16)$, and similarly concerning malignant promyelocytes percentage in blood film and bone morrow and coagulation study with induction outcome $(p>0.05)$. (Table 4$)$ 
The Medical Journal of Basrah University

(2021); 39(1): 21-30

High risk stratification had an impact on failure of induction therapy secondary to death in $33.3 \%$, with a significant association between risk stratification and induction outcome $(\mathrm{p}=0.04)$. There was no statistically significant association between classical morphology or variant APL form with early induction outcome $(p=0.61)$.

The protocol of induction has influenced the induction outcome; but with no statistical significance $(p=0.38)$. Only $4.5 \%$ of patients with ATRA+ATO had failure of induction, in comparison to $15.1 \%$ of those who had received ATRA+chemotherapy.

The duration of induction was statistically associated with induction outcome $(\mathrm{p}=0.006)$, as shorter than 30 days of induction had attributed with failure outcome in $35.3 \%$ unlike those with longer $\geq 30$ days duration of induction. (Table 5)

\begin{tabular}{|c|c|c|c|c|}
\hline \multirow[b]{2}{*}{ Test } & \multirow[b]{2}{*}{ Mean value } & \multicolumn{2}{|c|}{$\begin{array}{l}\text { Induction } \\
\text { outcome }\end{array}$} & \multirow{2}{*}{$\begin{array}{c}\mathrm{P} \\
\text { value }\end{array}$} \\
\hline & & $\begin{array}{c}\text { Death } \\
\text { No. }\end{array}$ & $\begin{array}{l}\text { CR } \\
\text { No. }\end{array}$ & \\
\hline \multirow[t]{3}{*}{ CBC } & 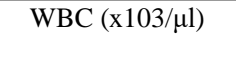 & 24.1 & 8.4 & $\begin{array}{c}0.038 \\
*\end{array}$ \\
\hline & Haemoglobin $(\mathrm{g} / \mathrm{dl})$ & 6.5 & 8.5 & $\begin{array}{l}0.006 \\
*\end{array}$ \\
\hline & Platelets $(\mathrm{x} 103 / \mu \mathrm{l})$ & 22.7 & $\begin{array}{c}39 . \\
7\end{array}$ & $0.16^{*}$ \\
\hline $\begin{array}{l}\text { Blood } \\
\text { film }\end{array}$ & $\begin{array}{c}\text { Malignant } \\
\text { Promyelocytes } \%\end{array}$ & 32.5 & $\begin{array}{c}33 . \\
9\end{array}$ & $0.91 *$ \\
\hline $\begin{array}{c}\text { BM } \\
\text { study }\end{array}$ & $\begin{array}{c}\text { Malignant } \\
\text { Promyeloctes } \%\end{array}$ & 47.5 & $\begin{array}{c}66 . \\
2\end{array}$ & $0.12 *$ \\
\hline \multirow[t]{2}{*}{$\begin{array}{l}\text { Coagulat } \\
\text { ion study }\end{array}$} & PT (sec) & 17.5 & $\begin{array}{c}55 . \\
3\end{array}$ & $0.75^{*}$ \\
\hline & PTT (sec) & 33.2 & 32 & $\begin{array}{l}0.702 \\
*\end{array}$ \\
\hline \multicolumn{5}{|c|}{$\begin{array}{c}\text { CR, complete remission } \\
* \text { Student } \mathbf{T} \text { test, significant } \leq 0\end{array}$} \\
\hline
\end{tabular}

Overview of Iraqi experience in management of acute promyelocytic leukemia

Kaplan Meier analysis has showed that the 1-year overall survival was $84.5 \%$ (at end time for data collection, nine patients were still within consolidation courses and not completing one year from time of diagnosis). (Figure 3)
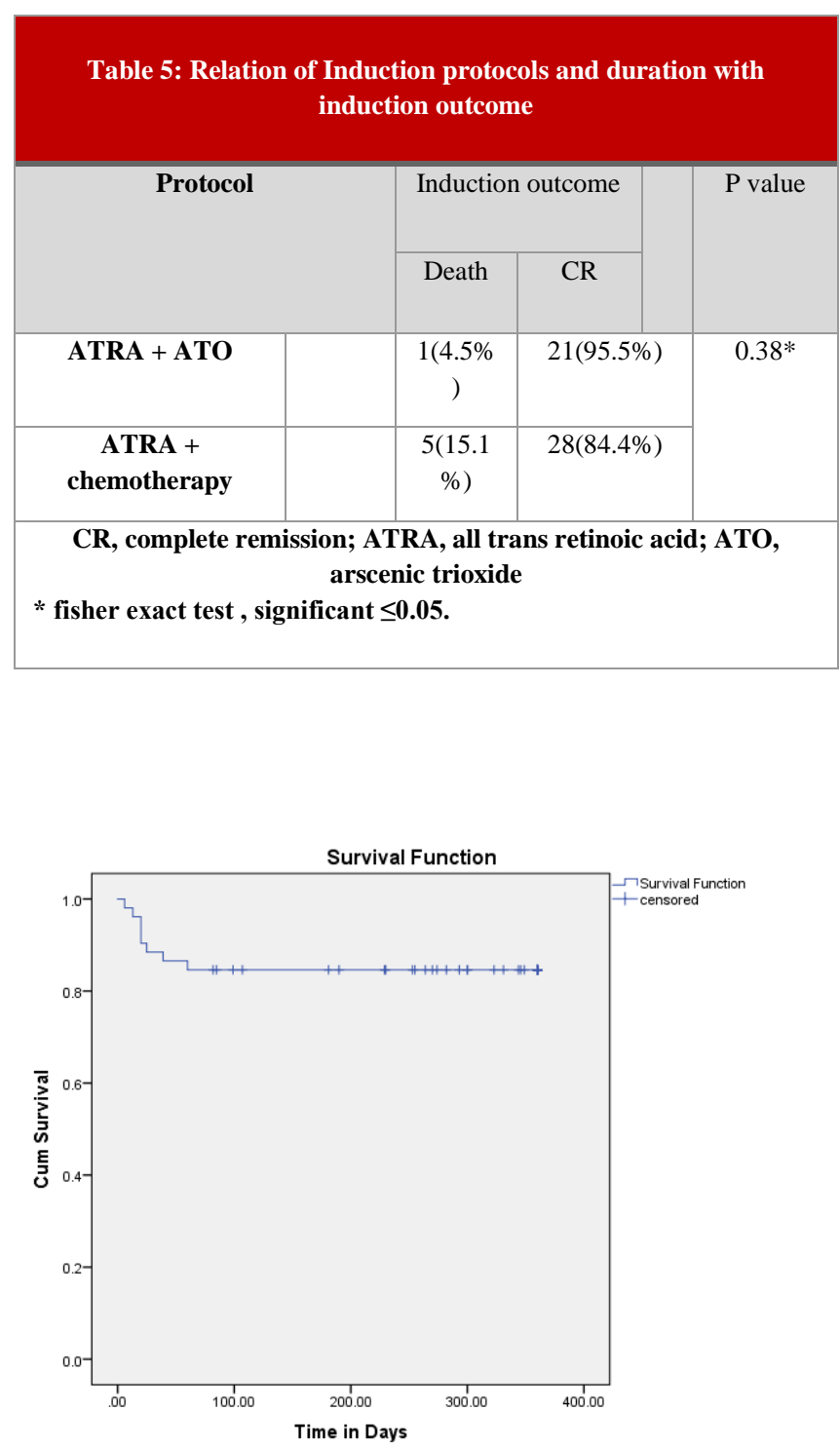

Figure 3: Kaplan Meier survival analysis for 1-year overall survival 
Survival distributions for the different levels of risk stratification had showed that, the mean survival in high risk was the lowest (204 days) while the highest was found in low risk (300 days) with significant difference in survival distributions $(p=0.035)$. (Figure 4)

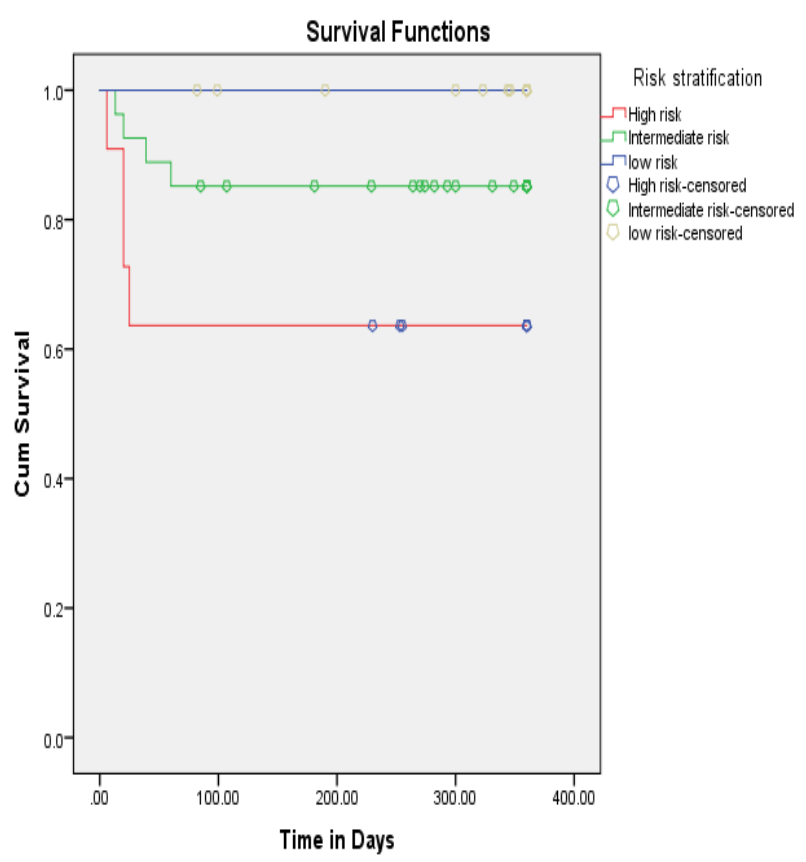

Figure 4: Survival analysis according to risk stratifications

\section{Discussion}

APL in general is a disease of young age group, and this was true for the current study, as the mean age was 33.1 years, which is in agreement to other Iraqi studies; Al-Shemari et al. 2005, ${ }^{14}$ and Ahmed, et al. 2018. ${ }^{15}$ The female gender slightly dominates, which was also seen in Pakistan APL patients (Sadia Sultan et al, 2015) with a male to female ratio of $1.2: 2^{16}$ but in contrary with Al-Shemari et al. 2005, ${ }^{14}$ Ahmed, et al. 2018, ${ }^{15}$ and Cunningham et al. $1989{ }^{17}$.

There is a seasonal predilection for APL manifestation, as more than one third of the cases were diagnosed during Winter (December-
February). This seasonality preference is also shown in a US study about seasonality in all AML subtypes, that the months of AML case diagnosis in which annual peaks in the overall count were observed during December and January, Calip et al. 2013. ${ }^{18}$ A similar predilection is also shown to be true with APL in a study done in Brazil, which concluded that the correlations found between rainfall and number of cases of APL could be related to the dispersion of pollutants into the environment, Barroso KS et al. 2013. ${ }^{19}$ An other explanation is by immunity changes over different seasons, as proposed by Randy J. Nelson, and Gregory E. Demas, , Nelson RJ et al $1996 .{ }^{20}$

Bleeding tendency is a common presentation, which is similar to Al-Shemari et al. 2005, 14 Khorshid O et al 2011, ${ }^{21}$ and Bajpai et al 2007, ${ }^{22}$ reprts. Thrombosis was an initial presentation in $5.1 \%$ of cases, which is in agreement with Ahmed, et al. 2018 Chang et al., 2013; and Mitrovic et al., 2015. ${ }^{15}$

The incidence of thrombosis in APL is higher than in other subtypes of acute myeloid leukemia and risk of thrombosis has been associated with elevated WBC count and presence of FLT3-internal tandem duplication (Breen et al., 2012). ${ }^{16}$

Based on the risk score, about half of patients were of an intermediate risk while the least common category was the high risk. In similarity, Bajpai et al $2007^{22}$ and in the larger GIMEMA and PETHEMA trials (Sanz et al., 2000). ${ }^{16}$

At the end of induction course; about $86.2 \%$ of patients have complete remission which is a higher induction $\mathrm{CR}$ than that of Al-Shemari et al. $2005(73 \%){ }^{14}$ Ahmed et al $2018(68 \%){ }^{15}$ and Cunningham et al $1989(75 \%) .{ }^{17}$ This clearly improving $\mathrm{CR}$ rate, may reflect the increasing 
awareness, better supportive care, availability and early initiation of ATRA in our hematology centers.

In most of cases of death, there was more than one cause, the highest attribution was for infection and hemorrhage. This is higher than that of Ahmed et al 2018, in which the main cause was also infection (36\%), followed by bleeding (28\%), as other causes were unrelated to the disease due to long duration of follow up. ${ }^{15}$

The protocol of induction had play a role on outcome although it was of non-statistical significance $(p=0.38)$ but this is in agreement with what has been concluded from the Phase III trial that randomized standard risk patients with APL to treatment with ATRA/chemotherapy vs. ATRA/ATO. In which the results showed noninferiority of ATRA/ATO regimen compared to ATRA/chemotherapy, Lo-Coco et al $2013 .^{23}$

It is found that the longer the duration of induction, the higher rate of $\mathrm{CR},(\mathrm{p}=0.006)$. This may be because most of death cases had occurred early in the induction course, the time in which the risk of coagulopathy is greater.

The one-year overall survival was $84.5 \%$, which is very much higher than that of Al-Shimary et al. $2005(66 \%){ }^{14}$ while it was $37.8 \%, 78 \%, 82 \%$ in Ahmed et al 2018, ${ }^{15}$ Cunningham et al $1989{ }^{17}$. This increasing OS reflects the success in APL management following the use of higher ATRA doses $45 \mathrm{mg} / \mathrm{m}^{2}$, and the introduction of ATO in most of Iraqi hematology centers.

\section{Conclusion:}

there is predilection to young patient disease, with more seasonal variation in presentation. Throughout the time an improving experiences and orientation with rapid diagnosis, risk stratification management as well as good supportive care can had achieved an appreciable early CR. Any combination of induction and consolidation chemotherapy can provide good long-term outcome but the use of non chemotharpy regimen may be advised for many instances with no drawback on the outcome. Longer duration for induction would give more deeper and durable response.

Acknowledgment: acknowledgments for all patients

Conflict of interest: The authors declare no conflict of interest.

\section{References}

1. Cicconi L, Lo-Coco F. Current management of newly diagnosed acute promyelocytic leukemia. Annals of Oncology. 2016 Apr 15;27(8):1474-81

2. Coco FL, Diverio D, Falini B, Biondi A, Nervi C, Pelicci PG. Genetic diagnosis and molecular monitoring in the management of acute promyelocytic leukemia. Blood. 1999 Jul 1;94(1):12-22.

3. Wang ZY, Chen Z. Acute promyelocytic leukemia: from highly fatal to highly curable. Blood. 2008 Mar 1;111(5):2505-15.

4. Laurent Degos. History of Acute Promyelocytic Leukemia. In: Oussama AblaFrancesco Lo CocoMiguel A. SanzEditors. Acute Promyelocytic Leukemia A Clinical Guide, $1^{\text {st }}$ ed. Cham, Switzerland: Springer International Publishing AG; 2018. p. 1-17.

5. Testa U, Lo-Coco F. Prognostic factors in acute promyelocytic leukemia: strategies to define high-risk patients. Annals of hematology. 2016 Apr 1;95(5):673-80.

6. Sanz MA, Grimwade D, Tallman MS, Lowenberg B, Fenaux P, Estey EH, Naoe T, Lengfelder E, Büchner T, Döhner H, Burnett AK. Management of acute promyelocytic leukemia: recommendations from an expert panel on behalf

Page 28 
of the European LeukemiaNet. Blood. 2009 Feb 26;113(9):1875-91.

7. Coombs CC, Tavakkoli M, Tallman MS. Acute promyelocytic leukemia: where did we start, where are we now, and the future. Blood cancer journal. 2015 Apr;5(4):e304.

8. Abedin S, Altman JK. Acute promyelocytic leukemia: preventing early complications and late toxicities. Hematology 2014, the American Society of Hematology Education Program Book. 2016 Dec 2;2016(1):10-5.

9. Daver N, Kantarjian H, Marcucci G, Pierce S, Brandt M, Dinardo C, Pemmaraju N, GarciaManero G, O'Brien S, Ferrajoli A, Verstovsek S. Clinical characteristics and outcomes in patients with acute promyelocytic leukaemia and hyperleucocytosis. British journal of haematology. 2015 Mar;168(5):646-53.

10. Lo-Coco F, Di Donato L, Schlenk RF. Targeted therapy alone for acute promyelocytic leukemia. New England Journal of Medicine. 2016 Mar 24;374(12):1197-8.

11. Sanz MA, Fenaux P, Tallman MS, Estey EH, Löwenberg B, Naoe T, Lengfelder E, Döhner H, Burnett AK, Chen SJ, Mathews V. Management of acute promyelocytic leukemia: updated recommendations from an expert panel of the European LeukemiaNet. Blood. 2019 Apr 11;133(15):1630-43.

12. Testa U, Lo-Coco F. Prognostic factors in acute promyelocytic leukemia: strategies to define high-risk patients. Annals of hematology. 2016 Apr 1;95(5):673-80.

13. Kelaidi C, Chevret S, De Botton S, Raffoux E, Guerci A, Thomas X, Pigneux A, Lamy T, Rigal-Huguet F, Meyer-Monard S, Chevallier P. Improved outcome of acute promyelocytic leukemia with high WBC counts over the last 15 years: the European APL Group experience. Journal of clinical oncology. 2009 Jun 1;27(16):2668-76.
14. Al-Shemari IK, Jawad AM, Al Tameemi WF. All Trans Retinoic Acid (ATRA) therapy in acute promyelocytic leukemia AML-M3 Results of treatment of 29 Iraqi adult patients with AMLM3. Iraqi Journal of Community Medicine. 2012;25(2):119-23.

15. Ahmed AT, Yassin AK, Mohammed NS, Hasan KM. Acute promyelocytic leukemia: Epidemiology, clinical presentation, and outcome over a 10-year period of follow-up at Nanakali Hospital of Erbil city "Single-center study”. Iraqi Joural of Hematology. 2019;8(1):713.

16. Sultan S, Irfan SM, Ashar S. Acute Promyelocytic Leukemia: A single center study from Southern Pakistan. Asian Pac J Cancer Prev. 2015;16(17):7893-5.

17. Cunningham I, Gee TS, Reich LM, Kempin SJ, Naval AN, Clarkson BD. Acute promyelocytic leukemia: treatment results during a decade at Memorial Hospital. Blood. 1989 Apr 1;73(5):1116-22.

18. Calip GS, McDougall JA, Wheldon MC, Li CI, De Roos AJ. Evaluation of seasonality in the diagnosis of acute myeloid leukaemia among adults in the U nited S tates, 1992-2008. British journal of haematology. 2013 Feb;160(3):34350.

19. Barroso KS, Lorand-Metze I, Rego EM, Melo RA, Bittencourt R, Pasquini R, Fagundes E, Jacomo R, Chiattone CS, Maria de Lourdes LF, Metze K. Evaluation Of Seasonality In The Incidence Of Promyelocytic Leukemia In Brazil.

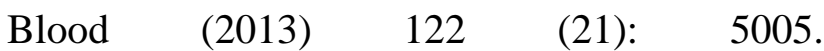
doi.org/10.1182/blood.V122.21.5005.5005

20. Nelson RJ, Demas GE. Seasonal changes in immune function. The Quarterly review of biology. 1996 Dec 1;71(4):511-48.

21. Khorshid O, Diaa A, El Moaty MA, El Fatah RA, El Dessouki I, El Hamid MA, El Noshokaty E, El Saied G, Fouad TM, Ramadan SM. Clinical 
features and treatment outcome of acute promyelocytic leukemia patients treated at cairo national cancer institute in Egypt. Mediterranean journal of hematology and infectious diseases. 2011;3(1).

22. Bajpai J, Sharma A, Kumar L, Dabkara D, Raina V, Kochupillai V, Kumar R. Acute promyelocytic leukemia: An experience from a tertiary care centre in north India. Indian journal of cancer. $2011 \mathrm{Jul}$ 1;48(3):316.
23. Lo-Coco F, Avvisati G, Vignetti M, et al. Retinoic acid and arsenic trioxide for acute promyelocytic leukemia. $\mathrm{N}$ Engl $\mathrm{J}$ Med. 2013;369:111-121. 